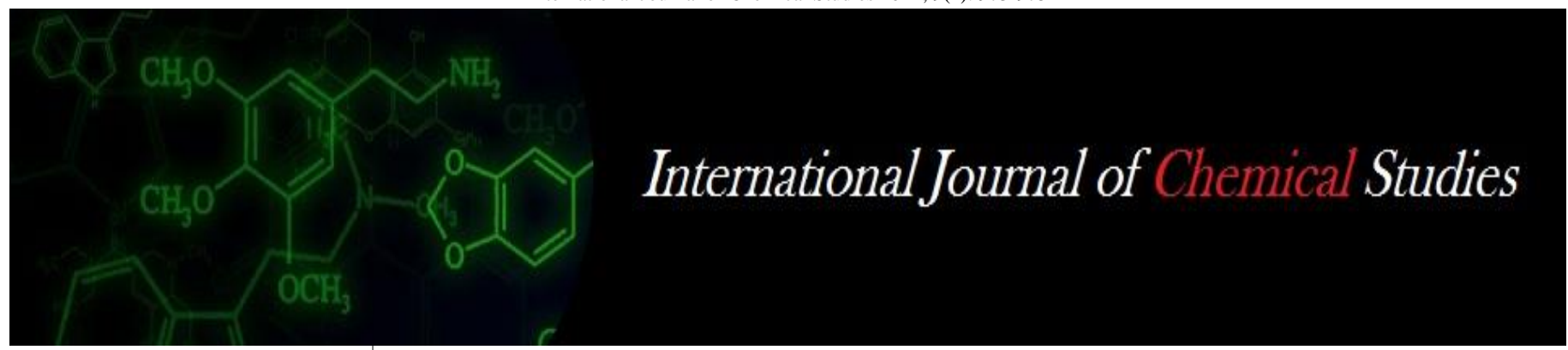

P-ISSN: 2349-8528

E-ISSN: 2321-4902

www.chemijournal.com

IJCS 2021; 9(1): 973-975

(C) 2021 IJCS

Received: 05-10-2020

Accepted: 12-11-2020

Khumlo Levish Chongloi

ICAR-Krishi Vigyan Kendra,

Chandel, Monsangpantha, ICAR

Research Complex for NEH

Region, Manipur Centre, India
Corresponding Author:

Khumlo Levish Chongloi

ICAR-Krishi Vigyan Kendra,

Chandel, Monsangpantha, ICAR

Research Complex for NEH

Region, Manipur Centre, India

\section{Assessment of different cropping system to enhance the productivity under rice fallow}

\section{Khumlo Levish Chongloi}

DOI: https://doi.org/10.22271/chemi.2021.v9.i1n.11350

\begin{abstract}
In Chandel district of Manipur, vast areas are lying fallow after the rice crop is harvested. Rice fallow areas can be better utilized in establishing winter ( $r a b i)$ crop, utilizing the residual soil moisture through different cropping sequences. To exploit these rice fallow areas with winter crops, location specific and economically viable technology for better performances of crop are required to be standardized through proper assessment of different cropping system to enhance the productivity. A Field experiments with four cropping systems were evaluated for two years during 2018-19 and 2019-20 at three locations of the farmers' field at Chandel district, Manipur state. The results revealed that the highest rice equivalent yield of $97.48 \mathrm{q} / \mathrm{ha}$ was recorded in rice-lentil cropping system followed by rice-fieldpea cropping system with $89.60 \mathrm{q} /$ ha and rice-rapeseed-mustard cropping system with $85.52 \mathrm{q} / \mathrm{ha}$ respectively, over the farmers' practice i.e. rice-fallow. On the other hand, the highest benefit: cost ratio of 2.93:1 was recorded in rice-fieldpea cropping system over all other cropping sequences which might be due to higher production and comparatively lesser production cost. Hence, there is a need to disseminate the improved technologies amongst the farmers with effective extension methods like training and demonstrations to utilise the existing farming situations rice fallow and convert monocropped area into double cropped areas for increasing the cropping intensity as well as to increase crop production and productivity.
\end{abstract}

Keywords: Cropping system, rice fallow, rice equivalent yield, productivity

\section{Introduction}

A cropping system refers to the type and sequence of crops grown and practices used for growing them. It encompasses all cropping sequences practiced over space and time based on the available technologies of crop production. Cropping systems have been traditionally structured to maximize crop yields. Conserving soil and water and maintaining long-term soil productivity depend largely on the management of cropping systems, which influence the magnitude of soil erosion and soil organic matter dynamics. While highly degraded lands may require the land conversion to non-agricultural systems for their restoration, prudently chosen and properly managed cropping systems can maintain or even improve soil productivity and restore moderately degraded lands by improving soil resilience. Crop diversification is an important option in sustainable agricultural systems.

Rice-fallow areas are those kharif paddy grown areas that were kept fallow in rabi season. The main reasons for leaving the lands fallow during the winter season are lack of irrigation, late harvesting of long-duration high yielding rice varieties, moistures stress at sowing during the Rabi crops due to early withdrawal of monsoon, waterlogging and excessive moistures in November/December, and nuisance like stray cattle and blue bulls (Ali and Kumar. 2009) ${ }^{[1]}$. The predominant cropping systems of Manipur are mainly rice based like rice-fallow, rice-rice, rice-rapeseed and rice vegetables, etc. where the diversification index is heavily influenced by rice. Besides, at farmer's level, potential productivity and monetary benefits act as guiding principles while opting for a particular crop/cropping system. Therefore, intensification and diversification of cropping system with the proper use of available limited residual moisture from rice field will provide higher yield as well as better net returns under the rainfed climatic conditions. In cropping system; inclusion of pulse, oilseed and vegetable is more beneficial than cereals after cereals. An intensification of cropping sequence is essential in the existing farming situation. Non- rice crop like oilseeds, pulses and vegetables are receiving more attention owing to higher price due to increased demand. 
Inclusion of these crops in a sequence changes the economics of the cropping sequences. In this perspective, there is an enormous opportunity to increase the total cropping area through strategic research in rice-fallows to generate maximum net profit per unit investment per unit time to farmers and to increased cropping intensity by converting monocropped area into double cropped.

\section{Materials and Methods}

Over the period of 2018-19 and 2019-20 an experiment of two years duration was carried out at three locations of the farmers' field of Chandel district to assess the different cropping system to enhance the productivity under rice fallow. In general, soils of the area under study were clay loam and medium to low in fertility status. The treatments comprised of four rice based cropping sequences viz. Rice (RC-Maniphou-13)-Fallow, Rice (RC-Maniphou-13) Rapeseed (TS-36), Rice (RC-Maniphou-13) - Fieldpea (Prakash) and Rice (RC-Maniphou-13) - Lentil (HUL-57).
The experiment was composed of two phases. In first phase, Rice was grown during the kharif season i.e., June-November followed by three winter crops grown during the rabi season i.e., November-February. All the recommended scientific package of practices was followed for every crop. The data on plant parameters and economic yield and economic returns from experimental fields and local practices adopted by the farmers were collected and evaluated. For comparison between different cropping systems, the yields of all the crops in the sequences were converted into rice equivalent yield (REY). The REY of the systems were calculated in terms of winter rice using the following formula:

$$
\mathrm{REY}=\Sigma \mathrm{Yi} \times \mathrm{Pi} / \mathrm{P}(\mathrm{p})
$$

Where, $\mathrm{Yi}=$ yield of different crops; $\mathrm{Pi}=$ price of respective crops and $\mathrm{P}(\mathrm{p})=$ price of rice.

\section{Results and Discussion}

Table 1: Average Yield attributing characters of Rice var. RC-Maniphou-13

\begin{tabular}{|c|c|c|c|c|}
\hline \multirow{2}{*}{ Parameters } & \multicolumn{2}{|c|}{$\mathbf{2 0 1 8 - 1 9}$} & \multicolumn{2}{c|}{ 2019-20 } \\
\cline { 2 - 5 } & Treatment & Farmer practice (Rice fallow) & Treatment & Farmer practice (Rice fallow) \\
\hline Plant height & 86.15 & 85.45 & 87.3 & 84.5 \\
\hline No. of tillers/hill & 8 & 7 & 9 & 6 \\
\hline No. of filled grains & 226 & 218 & 230 & 215 \\
\hline Test weight (gm) & 24.38 & 24.25 & 24.4 & 24.20 \\
\hline Yield (q/ha) & 59.50 & 56.43 & 61.30 & 54.40 \\
\hline
\end{tabular}

Table 2: Average Yield attributing characters of cropping sequence after Kharif rice

\begin{tabular}{|c|c|c|c|c|c|c|c|c|c|}
\hline \multirow{3}{*}{ Parameters } & \multicolumn{9}{|c|}{ Cropping sequence after rice } \\
\hline & \multicolumn{3}{|c|}{ Rapeseed } & \multicolumn{3}{|c|}{ Fieldpea } & \multicolumn{3}{|c|}{ Lentil } \\
\hline & 2018-19 & $2019-20$ & Average & 2018-19 & $2019-20$ & Average & 2018-19 & $2019-20$ & Average \\
\hline Plant height $(\mathrm{cm})$ & 67.50 & 68.35 & 67.93 & 38.89 & 39.55 & 39.22 & 35.60 & 36.50 & 36.05 \\
\hline No. of Siliqua/plant (pods/plant) & 135.25 & 136.20 & 135.73 & 8.51 & 8.55 & 8.53 & 98.50 & 99.35 & 98.93 \\
\hline No. of Seeds/siliqua (seeds/pods) & 6.50 & 6.75 & 6.63 & 5.45 & 5.55 & 5.50 & 1.96 & 2.15 & 2.06 \\
\hline Test weight $(\mathrm{gm})$ & 4.50 & 4.52 & 4.51 & 22 & 22.10 & 22.05 & 19.30 & 19.35 & 19.33 \\
\hline Yield (q/ha) & 9.25 & 9.55 & 9.40 & 13.90 & 14.10 & 14.00 & 10.15 & 10.45 & 10.30 \\
\hline
\end{tabular}

Table 3: Mean crop yield, rice-equivalent yield and Benefit: cost ratio under different cropping systems (mean of 2 years)

\begin{tabular}{|c|c|c|c|c|c|}
\hline \multirow{2}{*}{ Treatments } & \multicolumn{2}{|c|}{$\begin{array}{c}\text { Mean crop yield } \\
\text { (q/ha) }\end{array}$} & \multicolumn{2}{c|}{$\begin{array}{c}\text { Rice equivalent } \\
\text { yield(q/ha) }\end{array}$} & \multirow{2}{*}{$\begin{array}{c}\text { B:C } \\
\text { ratio }\end{array}$} \\
\cline { 2 - 5 } & Kharif & Rabi & Rabi & Total & \\
\hline Rice-Fallow & 55.42 & - & & 55.42 & $2.49: 1$ \\
\hline Rice-Rapeseed & 59.20 & 9.40 & 85.52 & 144.72 & $2.63: 1$ \\
\hline Rice-Fieldpea & 61.60 & 14.00 & 89.60 & 151.20 & $2.93: 1$ \\
\hline Rice-Lentil & 60.40 & 10.30 & 97.48 & 157.88 & $2.79: 1$ \\
\hline
\end{tabular}

\section{Yield attributing traits of rice and cropping sequence after Kharif rice}

The data on different yield characters were recorded from three different locations of the farmers' field. The average mean yield of rice from demonstrated field during 2018-19 and 2019-20 was recorded to be $59.50 \mathrm{q} / \mathrm{ha}$ and $61.30 \mathrm{q} / \mathrm{ha}$ against farmer practise (Rice fallow) $56.43 \mathrm{q} / \mathrm{ha}$ and 54.40 $\mathrm{q} /$ ha respectively (Table-1). Increased in yield of rice may be due to inclusion of legume in the cropping sequences over the farmers' practice i.e. rice-fallow. The findings are in close confirmation with the findings of Avasthe et al. (2019).

The average mean yield of different crops in rice based cropping sequence such as Rapeseed-mustard, fieldpea and lentil during 2018-19 and 2019-20 were 9.40 q/ha, 14.00 q/ha and $10.30 \mathrm{q} / \mathrm{ha}$ respectively (Table-2). Inclusion of short duration low water requiring legumes offered excellent opportunity to utilize carry-over residual soil moisture in rice fallow. Crop diversification has been recognized as an effective adaptation option for farmers for risk mitigation. (Lal et al. 2017) ${ }^{[4]}$.

\section{Rice equivalent yield and Benefit: cost ratio of rabi crops and cropping system}

Table -3 presents the mean crop yield of two years rice equivalent yield ( $\mathrm{q} / \mathrm{ha}$ ) of all the rabi crops and cropping system. The highest rice equivalent yield of $97.48 \mathrm{q} / \mathrm{ha}$ was recorded in lentil grown during rabi after rice followed by fieldpea with $89.60 \mathrm{q} /$ ha and rapeseed-mustard with 85.52 $\mathrm{q} / \mathrm{ha}$. Here we can see that different rice based cropping sequences influenced the average rice equivalent yield of the system. On the other hand, the highest benefit: cost ratio of 2.93:1 was recorded in rice-fieldpea cropping system over all other cropping sequences which might be due to higher production and comparatively lesser production cost. Similar results were also reported by Kalita et al. (2018) ${ }^{[3]}$. 


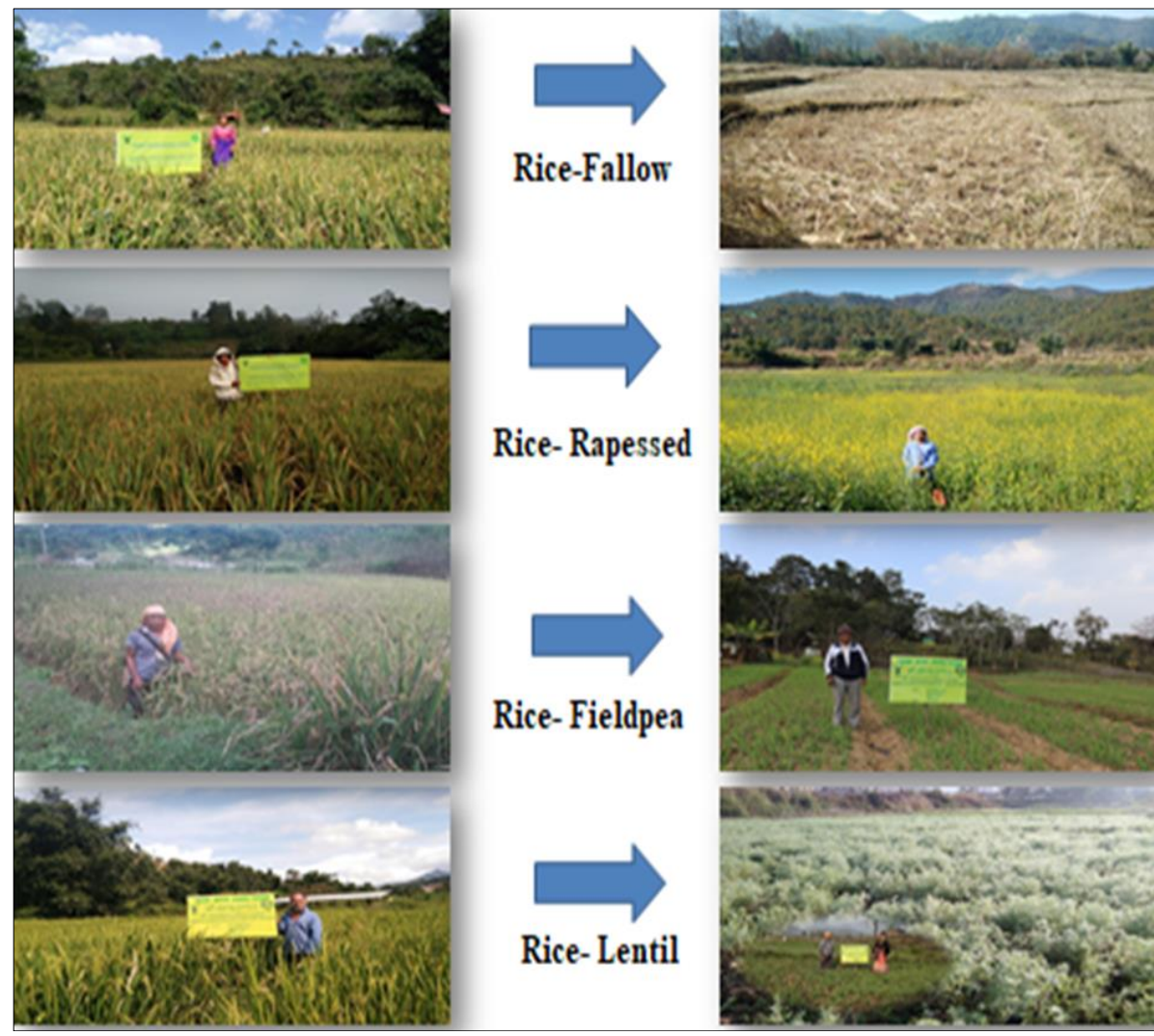

Fig 1: Assessment of different cropping system to enhance the productivity under rice fallow

\section{Conclusion}

From the two years study, it can be realized that the existing rice based cropping system of Chandel district, Manipur can be improved by inclusion of crops like lentil, fieldpea and rapeseed during rabi season instead of leaving the land fallow after rice. Diversification of the existing cropping system will enhance the productivity and economic point of view. Therefore, it can be recommended that growers can wisely select the cropping sequence as alternative to rice-fallow for increasing productivity as well as for sustaining their livelihood security.

\section{References}

1. Ali M, Kumar S. Major technological advances in pulsesIndian scenario. Milestones in Food Legumes Research, 20 p. (Eds. M Ali and S Kumar). Indian Institute of Pulses Research, Kanpur, India. MoA (2009). Report of Expert Group on Pulses. Department of Agriculture and Cooperation, Ministry of Agriculture, Govt. of India, New Delhi 2009, 9-10.

2. Avasthe RK, Babu S, Singh R, Yadav GS, Kumar A. Productivity and profitability assessment of organically grown vegetables embedded in rice based cropping sequences in Sikkim Himalayas, North East India. J Environ. Biol 2020;41:111-117.

3. Kalita J, Deka B, Kalita DN. Assessment of Rice-Based Cropping Systems for Maximizing Productivity and Profitability in Kamrup District of Assam. International Journal of Agriculture Sciences 2018;10(18):7209-7211.

4. Lal B, Gautam P, Panda BB, Raja R, Singh T, Tripathi R et al. Crop and varietal diversification of rainfed rice based cropping systems for higher productivity and profitability in Eastern India. PLoS ONE 2017;12(4):e0175709. https:// doi.org/10.1371/journal.pone.0175709 